\title{
METODE KISAH DALAM MENINGKATKAN MOTIVASI BELAJAR DAN KEMAMPUAN BERCERITA PADA PEMBELAJARAN SEJARAH KEBUDAYAAN ISLAM DI MADRASAH IBTIDAIYAH
}

\author{
Siti Nur Azizeh \\ Pascasarjana Magister Pendidikan Agama Islam UIN Sunan Ampel Surabaya \\ e-mail: azizehsitinur@gmail.com
}

\begin{abstract}
ABSTRAK
Pembelajaran Sejarah Kebudayaan Islam cenderung monoton, karena biasanya materi yang disampaikan dengan metode ceramah dan tanpa disertai dengan media pembelajaran. Hal ini membuat minat dan motivasi siswa menurun, sehingga materi yang dijelaskan tidak dapat diterima dan dipahami dengan mudah. Mengakibatkan sulitnya untuk menceritakan ulang tentang kisah (materi) yang telah guru sampaikan. Oleh sebab itu, guru dituntut untuk memberikan inovasi, guna terciptanya pembelajaran yang menyenangkan. Misalnya, menerapkan metode kisah untuk menyampaikan materi pelajaran. Tujuan dari Penelitian yaitu untuk dapat mengetahui penerapan metode kisah pada pembelajaran Sejarah Kebudayaan Islam terhadap peningkatan motivasi belajar dan kemampuan bercerita. Metode penelitian ini dengan pendekatan deskriptif, jenis penelitiannya berupa kajian kepustakaan. Teknik yang digunakan dalam mengumpulkan data yakni dengan menelaah berbagai buku, literatur dan catatan yang berkaitan dengan penelitian. Disimpulkan bahwa dengan metode kisah dapat memberikan dampak bagi motivasi dan kemampuan bercerita. Dengan metode kisah akan tercipta suasana belajar yang lebih menyenangkan, sehingga dapat mempengaruhi peningkatan motivasi belajar. Dengan ditandai adanya dorongan dari diri peserta didik berupa semangat dan rasa ingin tahu terhadap pelajaran Sejarah Kebudayaan Islam. Metode kisah yang disertai media gambar dapat menguatkan daya ingat peserta didik mengenai alur kisah sejarah. Sehingga dapat meningkatkan kemampuan bercerita tentang kisah tersebut, karena ketika ingin menceritakan ulang sebuah kisah dibutuhkan daya ingat yang tinggi khususnya terhadap alur cerita. Adapun tahap-tahap dalam penerapan metode kisah yang perlu diperhatikan oleh para pendidik yaitu meliputi, perencaan, penyajian materi,
\end{abstract}


korelasi, kesimpulan dan evaluasi. Mengenai perancangannya dapat disesuaikan dengan kebutuhan dan tujuan pembelajaran.

Kata Kunci: Kemampuan Bercerita, Metode Kisah, Motivasi Belajar

\begin{abstract}
Learning Islamic Cultural History tends to be monotonous, because it usually delivers material with the lecture method without being interpreted as learning media. This makes student interest and motivation decrease, so that the material described by the teacher cannot be accepted and understood properly. Resulting in difficulty in retelling the story (material) that the teacher has conveyed. Because of this, teachers are required to provide innovation, in order to create enjoyable learning. For example, applying the story method to convey subject matter. The purpose of this study is to determine the application of the story method in learning Islamic Cultural History to increase learning motivation and storytelling skills, the research method with a descriptive approach, the type of research in the form of literature review. The technique used in collecting data is by reviewing various books, literature and notes related to research. It is concluded that the story method can have an impact on observation and storytelling skills. With the ksah method it can provide a more pleasant learning atmosphere, so that it will affect the increase in learning motivation which is marked by the encouragement of students in the form of enthusiasm and curiosity about Islamic Cultural History lessons Merade stories accompanied by image media can strengthen students' memory regarding historical storylines So that it can improve the ability to tell stories about the story, because when you want to retell a story requires a high memory especially of the storyline. As for the stages in the application of the story method that educators need to pay attention to, planning, presentation of correlation material, conclusions and evaluation. Knowing the design can be tailored to your needs and requirements.
\end{abstract}

Keywords: Storytelling Ability, Story Method, Learning Motivation

Metode Kisah dalam Meningkatkan Motivasi Belajar dan Kemampuan Bercerita 


\section{A. PENDAHULUAN}

Kegiatan belajar mengajar yang dilakukan oleh siswa merupakan kegiatan yang sangat penting dalam menentukan masa depannya. Oleh sebab itu dalam pembelajaran setiap siswa dituntut dapat mencapai tujuan pembelajaran, Dengan tercapainya tujuan tersebut, dapat dikatakan siswa berhasil dalam pendidikannya. Untuk mencapai tujuan pembelajaran perlunya perencanaan yang bagus agar dalam pelaksanaan kegiatan belajar dapat dilakukan dengan sistematis dan langkah-langkah yang benar.

Dalam merencanakan sebuah pembelajaran butuh yang namanya desain pembelajaran. Desain pembelajaran merupakan sebuah proses perancangan dan pengembangan kebutuhan peserta didik, tujuan pembelajaran, analisis bahan ajar, strategi pembelajaran dan mengavalusinya. Apabila komponen-komponen tersebut dirancang dengan baik maka terciptanya pembelajaran yang bermakna. Begitupun sebaliknya apabila guru tidak memiliki kemampuan dan kreativitas dalam merancang pembelajaran maka terciptanya pembelajaran yang biasa saja. Pembelajaran yang monoton akan mempengaruhi semangat serta motivasi belajar, sehingga dapat mengakibatkan kurangnya pemahaman dalam menangkap materi pelajaran yang dijelaskan.

Merancang pembelajaran yang menarik butuh kreativitas seorang guru. Khususnya dalam menyampaikan materi kepada peserta didik. Guru dituntut memberikan inovasi dalam merancang sistem pembelajaran yang bermakna dan menarik, agar munculnya gairah belajar. Oleh sebab itu sebaiknya guru menerapkan metode pembelajaran yang tepat, dengan menyesesuaikan karakteristik serta kebutuhan siswa, yang membuat kegiatan belajar dan mengajar tidak lagi monoton, kaku dan membosankan. Sebagaimana yang tertuang dalam Undang-Undang RI Nomor 20 Pasal 40, ayat (2) tahun 2003 tentang Sistem Pendidikan Nasional yang berbunyi:

"Guru dan tenaga kependidikan berkewajiban: (1) Menciptakan suasana pendidikan yang bermakna, menyenangkan, kreatif, dinamis, dan dialogis, (2) Mempunyai komitmen secara profesional untuk meningkatkan mutu pendidikan, dan (3) memberi teladan dan menjaga nama baik lembaga, profesi dan kedudukan sesuai dengan kepercayaan 
yang diberikan kepadanya". 1

Berdasarkan bunyi undang-undang di atas dapat dijadikan pedoman dan pengingat bagi para guru bahwa, tugas seorang guru tidak hanya mencerdaskan anak bangsa, tetapi juga memberikan sebuah pengalaman belajar yang menyenangkan. Dengan memberikan pengalaman belajar yang menyenangkan dapat menjadi sebuah indikator munculnya motivasi belajar dalam diri seorang peserta didik. Akan ada perbedaan respon peserta didik antara mengikuti pembelajaran yang menyenangkan dan pembelajaran yang monoton.

Pembelajaran yang menyenangkan seharusnya diciptakan dalam setiap mata pelajaran, terlebih lagi pada pembelajaran Pendidikan Agama Islam. Pembelajaran tersebut cenderung masih monoton, kurangnya para pendidik dalam menggali berbagai metode dalam penyampaian materi, ${ }^{2}$ khususnya pada pelajaran Sejarah Kebudayaan Islam. Pelajaran ini merupakan pelajaran agama yang membahas tentang peristiwa penting di masa lampau yang menjadi bagian sejarah Islam, seperti tentang tokoh-tokoh keislaman dan asal-usul kebudayaan Islam. Pelajaran ini dirasa sangat penting untuk membentuk karakter diri peserta didik. Sebab di dalamnya mengandung kisah-kisah yang sangat menginspirasi dan memotivasi. Dengan mempelajari sejarah Islam, peseta didik dapat mengambil pelajaran atau hikmah yang terkandung dalam kisah-kisah. Oleh sebab itu pembelajaran Sejarah Kebudayaan Islam hendaknya menjadi sebuah pembelajaran yang berkmakna dan menyenangkan. Namun pada kenyataannya pembelajaran ini, menjadi pelajaran yang cenderung membosankan.

Kegiatan belajar mengajar materi Sejarah Kebudayaan Islam di sekolah-sekolah selama ini terkesan tidak menarik. Metode yang biasanya digunakan yaitu berceramah, yang berpusat kepada guru sedangkan peserta didik hanya mendengarkan saja. Pembelajaran yang monoton seperti ini cenderung membuat siswa mudah bosan dan merasa

${ }^{1}$ Presiden Republik Indonesia, "Undang-Undang Republik Indonesia Nomor 20 Tahun 2003 Tentang Sistem Pendidikan Nasional," 2003.

2 Syibran Mulasi, "PROBLEMATIKA PEMBELAJARAN PAI PADA MADRASAH TSNAWIYAH DI WILAYAH BARAT SELATAN ACEH," Jurnal Ilmiah Islam Futura 18, no. 2 (October 11, 2019): 276. 
jenuh, sehingga sering terjadi peserta didik tertidur saat mendengarkan penjelasan guru. Permasalahan tersebut memang sering terjadi, bahkan hampir dalam semua mata pelajaran.

Agar pembelajaran tidak monoton, hendaknya guru atau pendidik memberikan inovasi pada metode pembelajaran yang diterapkan. Seperti mengubah metode ceramah dengan menggunakan metode kisah. Metode kisah dirasa sangat sesuai bila diterapkan untuk pembelajaran Sejarah Kebudayaan Islam, karena meteri yang terkadung membahas tentang kisah-kisah islam di masa lampau.

Metode kisah merupakan cara untuk penyampaian pesan atau materi dengan bercerita secara kronologis tentang peristwa yang telah terjadi. Metode kisah banyak ditemukan dalam kitab Al-Qur'an maupun Hadis, kisah-kisah yang terdapat dalam kedua hukum Islam tersebut sangat diakui kevalidannya. ${ }^{3}$ Kisah-kisahnya meliputi tentang kisah sejarah Islam, kisah tentang Nabi, kisah peperang dan kisah tentang peristiwaperistiwa penting dalam sejarah Islam yang banyak tercantum pada alQur'an maupun Hadis.

Metode kisah diharapkan dapat meningkatkan motivasi peserta didik, dengan begitu dapat mempermudah dalam memahami materi yang disampaikan. Apabila pemahaman telah didapat, maka dengan mudah peserta didik menjelaskan atau menceritakan kembali kisah yang disampaikan oleh guru. Metode kisah yang disampaikan hendaknya disertai dengan media pembelajaran, seperti halnya menggunakan media gambar. Diharapkan dengan penggunaan media gambar saat berkisah dapat menguatkan daya ingat peserta didik.

Sebagaimana penelitian terdahulu, yang dilakukan M. Irfangi dikatakan bahwa metode kisah yang dipraktikkan dalam proses belajar mengajar Akidah Akhlak dinilai sangat efektif. Sehingga dapat membantu siswa dalam proses belajar, terutama dalam menangkap dan memahami materi. Selain itu nilai-nilai moral yang terkandung dapat menjadi tauladan dalam bersikap dan bertindak. ${ }^{4}$ Senada dengan

${ }^{3}$ Siti Aminah Lubis, "Penerapan Metode Kisah Dengan Media Audiovisual Dalam Meningkatkan Hasil Belajar Sejarah Kebudayaan Islam Siswa Kelas X Madrasah Aliyah Negeri 1 Padangsidimpun” (Institut Agama Islam Negeri Padangsisimpuan, 2019).

${ }^{4}$ M. Irfangi, "Implementasi Metode Kisah Dalam Pembelajaran Akidah Akhlak Di Madrasah Aliyah," Jurnal Kependidikan 5, no. 1 (2017): 79. 
penelitian M. Irfangi mengenai metode kisah yang dilakukan oleh Arifin Haq disimpulkan bahwa metode kisah dapat menciptakan pembelajaran yang menyenangkan dan dapat menghidupkan serta memuaskan rasa keingintahuan pada peserta didik. Dengan metode kisah siswa lebih berkonsentrasi dan fokus pada materi yang disampaikan, selain itu dapat memberikan ilustrasi dari konsep-konsep materi akhlak dengan lebih nyata, dan lebih jelas. Sehingga mudah dalam memahami materi tersebut, dan ketuntasan belajar meningkat sebesar $96 \% .^{5}$ Dikatakan pula pada penelitian yang dilakukan oleh Muchtadir bahwa penerapan metode kisah dengan model pembelajaran kontekstual, telah terjadi peningkatan terhadap hasil belajar peserta didik pada pelajaran SKI. $^{6}$ Dalam penelitian Evi Yuliana Sari, juga mengatakan bahwa dengan metode kisah terjadi peningkatan hasil nilai siswa sehingga dapat dikatakan tuntas dalam pembelajaran Sejarah Kebudayaan Islam,. ${ }^{7}$ Selain itu metode kisah berbasis al-Qur'an dapat di gunakan untuk membentuk karakter siswa sebagaimana penelitian yang dilakukan Mamik Rosita, dijelaskan dalam penelitian ini bahwa dengan cara mengintegrasikan bahan pembelajaran PAI yang berkaitan dengan cerita di Al-Quran disertai mengidentifikasi dengan nilai-nilai karakter yang terdapat dalam cerita tersebut. ${ }^{8}$ Dijelaskan juga dalam penelitian Bunyanul Arifin bahwa metode kisah merupakan salah satu metode dalam pendidikan Islam yang berbasis al-Qur'an dan Sunnah yang penting dalam mendidik karakter anak. Dengan menjadi sosok yang dapat diteladani dan mempelajari teknik-teknik berkisah, dapat dijadikan cara dalam

${ }^{5}$ Arifin Haq, "Ketuntasan Belajar Siswa Pada Mata Pelajaran PAI Melalui Metode Kisah Di SD Islami Jiwa Nala Surabaya," Mukammil: Jurnal Kajian Keislaman 1, no. 2 (2018): 237.

${ }^{6}$ Muchtadir, "Meningkatkan Hasil Belajar Peserta Didik Pada Mata Pelajaran SKI Melalui Penerapan Metode Kisah Dengan Model Pembelajaran Konstektual Di Kelas XI MA DDI Hasanuddin Kabupaten Maros” (Skripsi, UIN Alauddin Makassar, 2019), xiii.

7 Evi Yuliana Sari, "Penerapan Metode Kisah Pada Pembelajaran Sejarah Kebudayaan Islam Kelas III MIN 8 Bandar Lampung" (Skripsi, Universitas Islam Negeri Raden Intan, 2017), ii.

8 Mamik Rosita, "MEMBENTUK KARAKTER SISWA MELALUI METODE KISAH QURANI," FITRAH:Jurnal Kajian Ilmu-ilmu Keislaman 2, no. 1 (June 1, 2016): 70. 
mendidik karakter anak. ${ }^{9}$ Sedangkan dalam penelitian Junaidi Arsyad, metode kisah memiliki relevansi dengan pendidikan Islam kontemporer, dalam penelitian ini dikatakan bahwa menggunakan metode kisah mengacu pada contoh yang dipraktikkan Rasulullah yang disesuaikan dengan perkembangan pendidikan kontemporer dapat membina dan membentuk kepribadian masyarakat maupun peserta didik dengan melalui informasi dan kebenaran yang disampaikan dalam kisah. ${ }^{10}$

Dari beberapa penjelasan mengenai penelitian terdahulu tentang metode kisah dapat diketahui bahwa penelitian-penelitian tersebut lebih fokus pada peningkatan hasil pembelajaran dan pembentukan karakter. Berbeda dengan yang penulis teliti yakni fokus pada peningkatan motivasi belajar dan kemampuan bercerita. Dengan begitu, fokus penelitian yang akan dilakukan penulis terdapat perbedaan dengan fokus beberapa penelitian terdahulu.

Selain itu dapat disimpulkan pula dari penelitian terdahulu bahwa metode kisah dapat menimbulkan respon dari peserta didik, berupa sikap antusias dan rasa ingin tahu pada materi yang disampaikan melalui berkisah. Hal ini ditunjukkan adanya peningkatan hasil belajar, yang berarti disebabkan oleh besarnya motivasi belajar. Maka dari itu, metode kisah dirasa penting untuk diteliti lebih lanjut karena untuk mengetahui keterkaitannya pada peningkatan motivasi belajar dan kemampuan bercerita pada pembelajarn SKI.

Dari pemaparan di atas penulis tertarik mengkaji lanjut dan lebih dalam mengenai penerapan metode kisah dalam pembelajaran SKI (Sejarah Kebudayaan Islam). Metode kisah yang digunakan penulis yaitu dengan media gambar. Upaya ini dilakukan oleh guru, berharap adanya peningkatan motivasi belajar dan kemampuan bercerita pada siswa.

\section{B. METODE PENELITIAN}

Metode pada penelitian ini dengan pendekatan deskriptif, yakni berusaha mengkaji sedalam mungkin dengan beberapa sumber yang dapat digunakan. Karena, tidak ada sebuah pengujian hipotesis pada tipe

${ }^{9}$ Bunyanul Arifin, "Mrtode Kisah Dalam Al-Qur'an Dan Sunnah Dan Urgensinya Dalam Pendidikan Karakter," Tadarus Tarbawy 1, no. 2 (2019): 123.

10 Junaidi Arsyad, "Metode Kisah Dan Relevansinya Dengan Pendidikan Islam Kontemporer," Tazkiya: Jurnal Pendidikan Islam 6, no. 1 (2017): 1. 
penelitian deskriptif. ${ }^{11}$ Oleh sebab itu, jenis penelitian yang digunakan berupa kajian kepustakaan (library research) yaitu dengan mengumpulkan berbagai data dan informasi baik itu berupa buku maupun karya tulis atau literatur-literatur yang relevan dengan objek penelitian. Pada penelitian ini mengkaji tentang metode kisah, tujuannya untuk mengetahui adakah peningkatan dalam motivasi belajar dan kemampuan bercerita dalam pembelajaran SKI.

Sedangkan teknik Pengumpulan datanya dengan cara menelaah berbagai buku, literatur dan catatan maupun laporan yang berkaitan dengan penelitian mengenai metode kisah, motivasi belajar, kemampuan bercerita dan Pembelajaran Sejarah Kebudayaan Islam. Kemudian setelah mendapatkan penjelasan dari berbagai sumber tersebut, maka data-data tersebut akan dianalisis dengan melihat adakah keterkaitan atau relevansi antara satu dengan yang lain. Sehingga dapat tercapainya tujuan penelitian dalam suatu kajian penelitian yang dapat menjawab ataupun menjadi solusi dari permasalah dalam penelitian ini.

\section{METODE KISAH MELALUI GAMBAR}

Metode kisah berasal dari dua kata yakni metode dan kisah. Kata metode berasal dari kata metha dan hodos yang merupakan bahasa Yunani, kata metha memiliki arti melewati, sedangkan kata hodos bermakna jalan atau cara. Jadi secara istilah, metode yaitu jalan yang akan dilewati atau digunakan agar dapat mencapai sebuah tujuan tertentu. ${ }^{12}$ Artinya dalam mencapai sebuah tujuan seseorang harus melalui sebuah jalan yang menuju pada tujuan tersebut. Jalan inilah yang disebut sebagai metode yang digunakan dalam mencapai sebuah tujuan.

Dalam pembelajaran, kedudukan metode sangatlah penting demi tercapainya tujuan pembelajaran. Metode merupakan sarana dalam penyampaian materi yang telah termuat dalam kurikulum, menjadikan peserta didik dapat menyerap dan memahaminya, menjadi sebuah

11 Cut Medika Zellatifanny and Bambang Mudjiyanto, “TIPE PENELITIAN DESKRIPSI DALAM ILMU KOMUNIKASI," Diakom : Jurnal Media dan Komunikasi 1, no. 2 (December 28, 2018): 84.

${ }^{12}$ Sunhaji, Strategi Pembelajaran Konsep Dasar, Metode Dan Teknik Proses Belajar Mengajar (Yogyakarta: Pustaka Senja, 2015), 39. 
konsep ilmu yang befungsi terhadap tingkah lakunya. ${ }^{13}$ Oleh sebab itu, pendidik hendaknya menggunakan metode pembelajaran yang tepat, demi menunjang tercapainya tujuan pembelajaran.

Sedangkan dalam bahasa Indonesia kata "kisah" serapan dari kata "qis\} ah" suatu kata dari bahasa Arab yang memiliki makna cerita. Dalam al-Qur'an ada banyak kata kisah yang disebutkan, yang bermakna tarikh atau sejarah yakni kejadian atau peristiwa yang telah terjadi pada zaman dahulu. ${ }^{14}$ Dengan demikian kisah bermakna sebuah cerita dari suatu kejadian atau peistiwa yang tejadi pada masa atau zaman dahulu.

Dari pengertian metode dan kisah yang dijelaskan di atas, apabila digabungkan menjadi satu mengandung sebuah pengertian bahwa, metode kisah adalah suatu jalan dalam proses pembelajaran dengan cara bercerita tentang peristiwa-peristiwa pada zaman dahulu. Dengan metode kisah guru dapat menyampaikan materi dalam bentuk bercerita atau berkisah yang didasarkan pada kisah sejarah. Metode kisah, dapat menceritakan peristiwa sejarah secara runtut, sesuai dengan alur peristiwa yang terjadi. Sehingga dapat mempermudah peserta didik dalam memahami alur peristiwa sejarah tersebut.

Menurut Mangun Budiyanto metode kisah adalah metode dalam pembelajaran Islam dengan menggunakan kisah-kisah dari peristiwa dan kejadian yang terjadi pada zaman dahulu. Metode kisah dan metode "alIbrah" sangat berkaitan erat. Metode "al-Ibrah" merupakan metode tentang merunungkan atau memikirkan peristiwa-peristiwa yang terjadi. Oleh kerana itu sangat bekaitan dengan metode kisah yang menceritakan tentang peristiwa atau kejadian dimasa lalu. ${ }^{15}$ Dengan bercerita tersebut seseorang akan berpikir dan merenungkan hikmah dibalik peristiwa yang terjadi. Pendapat lain mengartikan metode kisah sebagai cara yang digunakan dalam menyampaikan materi dengan bercerita secara runtut mengenai kejadian dari sebuah peristiwa yang sebenarnya memang terjadi atau hanya sebuah rekaan saja. Dalam upaya pembentukan akhlak, metode kisah memang sangat dianjurkan, melalui metode

\footnotetext{
${ }^{13}$ Haq, "Ketuntasan Belajar Siswa Pada Mata Pelajaran PAI Melalui Metode Kisah Di SD Islami Jiwa Nala Surabaya," 220.

${ }^{14}$ Nasir Baki, Metode Pembelajaran Agama Islam (Makassar: Alauddin Universitas Press, 2012), 64.

${ }^{15}$ Mangun Budiyanto, Ilmu Pendidikan Islam (Yogyakarta: Griya Santri, 2010), 56.
} 
tersebut peserta didik dapat mengambil pelajaran dari nilai-nilai yang tedapat di dalamnya, sehingga dapat menjadi suatu cerminan dalam berakhlak. ${ }^{16}$ Senada dengan pendapat ini, bahwa metode kisah merupakan cara untuk menyampaikan pesan atau materi pelajaran melalui bercerita dengan runtut mengenai terjadinya suatu hal, peristiwa, atau pengalaman baik yang bersifat faktual ataupun hanya rekaan. ${ }^{17}$ Dapat disimpulkan dari beberapa pengertian metode kisah yaitu suatu cara penyampaian kisah (materi) melalui bercerita tentang kronologi dari suatu kejadian atau peristiwa di masa lalu.

Salah satu dari banyaknya metode pembelajaran, metode kisah memang sangat menarik untuk dibahas lebih lanjut, seperti yang telah diketahui kisah sendiri mampu mengambil hati para pembaca atau pendengar terutama anak-anak. Banyaknya inovasi metode pembelajaran yang muncul saat ini, tidak semua metode tersebut tepat kegunaannya pada semua mata pelajaran di setiap jenjang, khususnya untuk jenjang Sekolah Dasar. Metode kisah memang sangat disukai oleh anak-anak, apalagi kalau dikemas dan disampaikan dengan sangat bagus, akan menambah daya tarik tersendiri.

Perlu diingat, fungsi kisah atau cerita tidak hanya sebagai hiburan, tetapi yang terpenting dapat digunakan sebagai cara agar tercapainya tujuan pembelajaran. Mendidik dengan cara berkisah atau bercerita dapat memberikan kesan yang menyenangkan dalam belajar dan mendorong semangat peserta didik dalam proses pembelajaran, dengan begitu materi (kisah) dapat diserap dengan baik. ${ }^{18}$

Terdapat perbedaan antara pengertian dari kisah, dongeng dan cerita. Kisah adalah cerita yang bersifat faktual dan nyata mengenai peristiwa-peistiwa dan biografi tokoh. ${ }^{19}$ Cerita umumnya bersifat

${ }^{16}$ Samsul Nizar and Zainal Efendi Hasibuan, Hadis Tarbawi (Jakarta: Kalam Mulia, 2011), 78 .

${ }^{17}$ Subur, Nilai Moral Berbasis Kisah (Yogyakarta: Kalimedia, 2015), 73-73.

${ }^{18}$ Amirullah and Heri Gunawan, Mencetak Anak Hebat (Jakarta: PT. Gramedia, 2014), 236.

${ }^{19}$ Subur, Nilai Moral Berbasis Kisah, 79. 
karangan atau fiksi, ${ }^{20}$ Sedangkan pengertian dongeng yakni sebuah cerita yang bercerita tentang peristiwa masa lampau baik yang bersifat nyata ataupun fiksi. ${ }^{21}$

Sebuah kisah hendaknya dikemas secara menarik serta dapat menimbulkan rasa ingin tahu seorang siswa, sehingga terciptanya pembelajaran yang aktif. Dapat pula dilakukan dengan cara memberikan pertanyaan atau memberikan tanggapan setelah guru bercerita. Kisah akan lebih bermanfaat apabila sesuai dengan kemamuan dan kebutuhan peserta didik. oleh karena itu guru seharusnya menyesuaikan teknik bercerita dengan tahap perkembangan peserta didik, baik dari bahasa yang disampaikan, media yang digunakan, maupun langkah-langkah yang telah disusun dalam pelaksanaannya. ${ }^{22}$

Bercerita, memiliki beberapa teknik yang dapat digunakan diantaranya adalah 1) dengan cara membaca cerita langsung dari sumber buku, 2) dapat menambahkan sebuah ilustrasi pada buku, contohnya gambar 3) dengan cara menggunakan papan flanel, 4) bercerita dengan memakai media boneka, dan 5) bercerita dengan bermain peran dalam suatu cerita. Dalam penelitian ini penulis menggunakan teknik bercerita dengan media gambar. Gambar yang digunakan bisa dari buku ataupun gambar yang telah disediakan oleh guru.

Dari beberapa media pembelajaran, media gambar dirasa tepat dalam menjelaskan sebuah kisah. Perpaduan yang sangat baik antara kata-kata dengan gambar dalam proses penyampaian informasi, pesan atau meteri pelajaran.

Pengertian media gambar menurut Sadiman, berpendapat bahwa bentuk media gambar termuat pada media grafis. Pengertian media grafis yaitu bagian dari jenis media visual, penggabungan dari titik, garis, simbol, dan gambar bertujuan menggambarkan suatu hal, ide ataupun peristiwa. Sedangkan kata media gambar merupakan bahasa yang lebih

\footnotetext{
${ }^{20}$ Dayu Tamara, “ Penerapan Metode Bercerita Untuk Meningkatkan Keterampilan Berbicara Anak Kelompok A Di TK Pertiwi Keprabon Polanharjo Klaten Tahun Pelajaran 2013/2014" (Skripsi, Universitas Muhammadiyah, 2014).

${ }^{21}$ Moeslichatoen R., Metode Pengajaran Di Taman Kanak-Kanak (Jakarta: PT. Rineka Cipta, 2004), 125.

${ }^{22}$ Hadisa Putri, "Penggunaan Metode Kisah Untuk Mengembangkan Nilai Moral Anak TK/MI," Jurnal Bioilmi 2, no. 2 (2016).
} 
sering digunakan. ${ }^{23}$ Pendapat lain, menyatakan bahwa media gambar memiliki fungsi sebagai penyampaian pesan dengan perantara gambar yang terhubung dengan indera penglihatan. Penyampaian pesan atau materi pada gambar akan tertuang dalam bentuk simbol, yang dapat dijadikan sebagai komunikasi visual. Tujuan menggunakan media gambar, selain dapat menarik perhatian, yang paling penting dapat memperjelas isi materi dan mengilustrasikan fakta atau informasi. ${ }^{24}$ Dari penjelasan media gambar di atas kesimpulannya adalah media gambar merupakan suatu perantara atau penghubung yang dapat mengantarkan pesan melalui media indra penglihatan yang disajikan dalam bentuk gambar, titik, garis dan simbol-simbol untuk memberikan gambaran yang nyata dan jelas terhadap materi, ide, gagasan, maupun peristiwa.

Penggunaan media gambar dalam pembelajaran hendaknya memenuhi syarat-syarat, diantaranya yaitu:

1. Harus Autentik: artinya gambar yang digunakan haruslah memiliki kesesuaian untuk menyampaikan fakta yang sesungguhnya.

2. Sederhana: memiliki arti yang jelas dan tidak berlebihan untuk menunjukkan poin-poin yang tertuang pada gambar sehingga peserta didik dapat mudah memahaminya.

3. Gambar yang digunakan memiliki kesesuaian dengan tujuan pembelajaran yang ingin dicapai.

4. Gambar hendaknya dapat menunjukkan objek untuk memperlihatkan peristiwa yang sesuai dengan tema yang dipelajari.

5. Gambar juga bisa digunakan dengan semaksimal mungkin agar tercapainya suatu tujuan pembelajaran. ${ }^{25}$

Penerapan metode kisah dengan menambahkan media gambar akan memiliki daya tarik tersendiri terhadap perhatian peserta didik dalam pembelejaran. Selain mendengarkan kisah, peserta didik juga dapat melihat gambar yang ditampilkan. Sehingga dapat memberikan gambar nyata tentang kisah yang sedang diceritakan. Materi (kisah) yang

${ }^{23}$ Arief Sadiman, Media pendidikan: Pengertian, Pengembangan dan Pemanfaatannya (Jakarta: Rajawali Pers, 2011), 28-29.

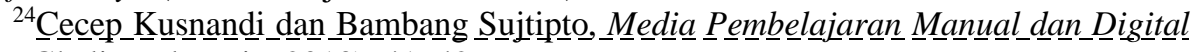
(Bogor: Ghalia_Indonesia, 2013), 41_-42.

${ }^{25}$ Ibid. 
diceritakan akan mudah diterima oleh peserta didik, sehingga mudah untuk dipahami.

\section{MOTIVASI BELAJAR}

Peran motivasi belajar sangatlah penting, oleh karena itu dalam diri setiap individu haruslah memiliki motivasi belajar, yang nantinya dapat menentukan tercapai atau tidaknya tujuan dan hasil belajar.

Motivasi belajar yakni sebuah keadaan dalam diri seseoang yang berupa dorongan untuk melakukan sesuatu agar tercapainya tujuan tertentu. Dari pendapat Mc Donald mengenai motivasi merupakan perubahan daya yang terjadi di dalam diri individu yang menimbulkan perasaan atau reaksi dalam mencapai tujuan. ${ }^{26}$ Sedangkan pendapat Woodwort motivasi merupakan satu kesatuan yang dapat membuat seseorang melakukan suatu kegiatan atau aktivitas agar tercapainya tujuan tertentu. Dengan demikian yang dimaksud motivasi yaitu sesuatu yang berupa dorongan dalam berperilaku guna tercapainya tujuan yang diinginkan. ${ }^{27}$ Bagian yang paling penting dalam motivasi yakni adanya aktivitas. Karena dari dorongan tersebut seseorang akan melakukan suatu tindakan yang berupa aktivitas baik berupa fisik maupun mental. ${ }^{28}$ Motivasi belajar adalah sebuah kekuatan yang dapat memberikan gerakan, pengarahan dan memelihara perilaku menuju suatu tujuan. ${ }^{29}$ Penulis menyimpulkan bahwa motivasi belajar yaitu suatu keadaan yang dapat mendorong atau membuat peserta didik untuk melakukan tindakan agar tercapainya tujuan tertentu, karena itu perlunya kegiatan dalam mencapainya.

Dalam proses pembelajaran motivasi dapat menjadi suatu keseluruhan kekuatan dalam menggerakkan diri siswa sehingga terjadinya aktivitas belajar, menjamin keberlangsungan proses belajar, dan mengarahkan kegiatan belajar pada tujuan yang akan dicapai.

${ }^{26}$ Kompri, Motivasi Pembelajaran Perspektif Guru dan Siswa (Bandung: PT Rosda Karya, 2016), 229.

${ }^{27}$ Wina Sanjaya, Kurikulum dan pembelajaran, Teori dan praktek Pengembangan Kurikulum KTSP (Jakarta: Kencana, 2010), 250.

${ }^{28}$ J. Lee and L. Martin, "Investigating Students' Perceptions of Motivating Factor of Online Class Discussions," Intrnational Review of Research in Open and Distance Learning 18, no. 5 (2017): 148-172.

${ }^{29}$ Ridwan Abdullah Sani, Inovasi Pembelajaran (Jakarta: Bumi Aksara, 2013), 49. 
Dorongan akan menjadi kekuatan tersendiri bagi peserta didik untuk lebih bekerja keras dalam memenuhi kebutuhan dan tujuan belajarnya. Secara tidak langsung motivasi terlibat dalam proses belajar dengan memberi energi, pengarahan, dan pertahan tingkah laku. ${ }^{30}$

Motivasi belajar dapat menjadi kekuatan mental karena mampu menggerakkan terjadinya kegiatan belajar. Motivasi belajar yang dialami peserta didik dapat berubah-ubah, tekadang naik dan turun. Rendahnya motivasi belajar, dapat mengakibatkan rendahnya kegiatan belajar yang dilakukan, sehingga hasil belajar menjadi kurang memuaskan. Agar motivasi belajar terus meningkat, maka yang dapat dilakukan oleh guru yaitu dengan menjadikan suasana belajar di kelas menyenangkan.

Tingginya motivasi yang dimiliki oleh peserta didik didalam dirinya akan timbul tindakan sungguh-sungguh dalam melaksanakan kegiatan belajarnya, serta lebih bersemangat dan bergairah. Sebaliknya jika motivasi belajarnya rendah, akan timbul rasa malas dalam melaksanakan kegiatan belajarnya, bahkan terasa berat untuk mengerjakan tugastugasnya. ${ }^{31}$

Dilihat dari sifatnya motivasi memiliki dua macam, diantaranya motivasi intrinsik dan motivasi ekstrinsik. Pengertian motivasi intrinsik yaitu motivasi yang kemunculannya berasal dari dalam diri seorang individu itu sendiri, contohnya peserta didik belajar karena adanya dorongan keinginan dari diri peserta didik untuk menambah pengetahuannya. atau seorang yang sering berenang karena dirinya suka berenang. Maka pada motivasi intrinsik pencapaian tujuan terdapat dalam aktivitas yang dilakukan. Sedangkan motivasi ekstrinsik yaitu motivasi yang kemunculannya datang dari luar diri individu, yakni motivasi datang disebabkan karena adanya suatu hal dari luar diri seseorang. Contohnya peserta didik yang belajar dengan sungguhsungguh demi mendapakan nilai yang bagus, atau seseorang yang latihan berenang karena ingin menjadi juara pada lomba renang. Dapat diketahui

\footnotetext{
${ }^{30}$ Norman Rudhumbu, "Motivational Strategies In The Teaching Of Primary School Mathematics In Zimbabwe," International Journal Of Education Learning And Development UK 2, no. 2 (2014): 78.

${ }^{31}$ Ramli Bakar, "The Effect Of Learning Motivation On Student's Productive Competencies In Vocational High School, West Sumatra," International Journal Of Asian Social Science 4, no. 6 (2014): 723.
} 
bahwa tujuan yang ingin dicapai dari motivasi ekstrinsik berasal dari luar kegiatan. ${ }^{32}$

Dalam pembelajaran, motivasi memiliki fungsi yang sangatlah penting, karena motivasi dapat menentukan besar tidaknya usaha yang dilakukan peserta didik dalam belajar. Motivasi memiliki tiga fungsi, diantaranya yaitu:

1. Mendorong adanya suatu tindakan atau perilaku yang berupa kegiatan. Tanpa adanya motivasi dalam diri peserta didik tidak akan muncul perilaku seperti halnya belajar.

2. Sebagai pengarah, berarti memberi arahan tindakan agar tercapainya tujuan tertentu yang diingiinkan.

3. Sebagai penggerak, berarti menggerakkan tindakan individu. Cepat atau lambatnya suatu pekerjaan yang dilakukan, sangat tergantung pada tinggi rendahnya motivasi dalam diri individu. ${ }^{33}$

Dari fungsi tersebut dapat dikatakan bahwa pentingnya motivasi belajar pada proses belajar. Jika motivasi belajar tinggi akan berpengaruh besar pada keberhasilan belajar peserta didik. Maka dari itu motivasi memiliki peran penting dalam setiap pembelajaran yang dilakukan peserta didik.

\section{E. KEMAMPUAN BERCERITA}

Kemampuan bercerita adalah kegiatan yang sering sekali ditemui anak dan merupakan salah satu yang tekandung dalam aspek perkembangan bahasa. Kegiatan bercerita sangat baik diterapkan pada anak-anak sekolah dasar, karena bisa digunakan sebagai latihan untuk mengemukakan ide-idenya secara lisan dan belajar mengkomunikasikannya. Selain itu peserta didik dituntut memiliki keberanian dalam melakukan kegiatan terutama bercerita. ${ }^{34}$

\footnotetext{
${ }^{32}$ Manner Tampubolon, "Upaya Guru Meningkatkan Motivasi Belajar Siswa," Sabilarrasyad 1, no. 1 (2016): 102.

${ }^{33}$ Angga, Dina Thalib, and Raja, "Motivasi Belajar, Kemandirian Belajar Dan Prestasi Belajar Mahasiswa Beasiswa Idikmisi Di UPBJJ UT Bandung," Jurnal Pendidikan Terbuka dan Jarak Jauh 15, no. 2 (September 2014): 83.

${ }^{34}$ Ni Made Wahyuni, Wayan Koyan, and Gde Wawan Sudatha, "Penerapan Metode Bermain Peran Berbantuan Media Gambar Berseri Untuk Meningkatkan Kemampuan Bercerita Anak Kelompok B Di Tk Dharma Kusuma," Jurnal PAUD 1, no. 1 (2013): 2.
} 
Bercerita ialah salah satu kemampuan dalam aspek berbahasa, tujuannya untuk memberikan dan menyebarkan informasi kepada para pendengar. Karena bercerita dapat memberi informasi dalam bentuk pengertian-pengertian dan makna-makna dengan begitu jelas. Kemampuan untuk bercerita tidak lepas dengan keterampilan berbicara, karena bercerita merupakan teknik dalam keterampilan berbicara.

Kegiatan bercerita dianggap penting sekali bagi seorang anak karena dapat memberikan dampak positif baginya. Dengan adanya aktifitas bercerita diharapkan dapat membantu peserta didik dalam melatih imajinasi yang dimiliki dan keterampilan berbahasanya dengan melalui kegiatan menceritakan kembali. Pendapat lain mengatakan yang dimaksud bercerita ialah suatu kegiatan seseorang yang dilakukan dengan lisan untuk diperdengarkan kepada seseorang ataupun beberapa orang mengenai susuatu yang harus disampaikan baik berupa informasi, pesan ataupun sebuah kisah yang untuk diperdengarkan dengan cara yang menarik dan menyenangkan. ${ }^{35}$ Dapat disimpulkan, bercerita ialah suatu kegiatan melalui lisan yang bertujuan menyampaikan sebuah informasi, atau kisah yang dapat melatih imajinasinya dan keterampilannya dalam berbahasa.

Cerita memiliki beberapa fungsi yang sangat penting bagi pendidikan seorang anak diantaranya adalah (1) sebagai media kontak batin yang terjadi antara pendidik (guru/orang tua) dengan siswa. (2) sebagai perantara, dalam menyampaikan pesan dan nilai-nilai moral yang terdapat dalam ajaran tertentu. (3) dapat menjadi sebagai metode dalam melatih peserta didik supaya mampu dalam melakukan proses indentifikasi diri dan perbuatan. (4) dapat berfungsi sebagai sarana dalam aspek pendidikan emosional (perasaan) peserta didik, (5) sebagai upaya dalam mengembangkan fantasi, imajinasi, dan kreativitas (6) sebagai media pendidikan bahasa pada peserta didik. ${ }^{36}$

Cerita atau kisah bila dikaitkan dengan cara penyampaiannya, maka berhubungan erat dengan kemampuan seseorang dalam bercerita. 2006), 64 .

${ }^{35} \mathrm{~N}$ Dhiena and dkk, Metode Pengembangan Bahasa (Jakarta: Universitas Terbuka, 2009), 2.

${ }^{36}$ Agus Bimo, Memahami Berbagai Aspek Bercerita (Jakarta: Raja Grafindo Persada, 
Apabila seseorang memiliki kemampuan bercerita dengan baik, maka dapat meningkatkan kemampuan berbicaranya, ditandai dengan berbicara secara runtut, jelas, lengkap dan objekif. Oleh karen itu dalam meningkatkan kemampuan bercerita, peserta didik perlu dilatih cara menyampaikan dan mengkomunikasikan suatu cerita dengan memperhatikan, urutan cerita, suara, lafal, itonansi, mimik muka, serta gerakan tubuh. Dengan memperhatikan aspek-asek yang terdapat dalam bercerita, maka akan terciptanya suatu cerita yang menarik bahkan membuat pendengar merasa terbawa oleh cerita tersebut.

\section{F. PEMBELAJARAN SEJARAH KEBUDAYAAN ISLAM}

Pada Pendidikan Agama Islam, terdapat beberapa mata pelajaran, salah satu diantaranya adalah mata pelajaran Sejarah Kebudayaan Islam. Mata pelajaran ini merupakan pelajaran yang wajib ada dan dipelajari terutama pada sekolah-sekolah dan perguruan tinggi yang berbasis Islam ${ }^{37}$ Sebagimana peraturan Kementrian Agama bahwa:

"Sejarah Kebudayaan Islam merupakan pelajaran yang berisi perjalanan hidup muslim dari masa ke masa dalam hal beribadah, bermuamalah, serta berakhlak dalam mengembangkan agama Islam yang dilandasi oleh akidah." 38

Pada setiap jenjang pendidikan Madrasah, akan dipertemukan dengan pelajaran Sejarah Kebudayaan Islam. Pelajaran ini membahas tentang perkembangan dan asal-usul peradaban Islam di antaranya seperti kisah peperangan, kisah-kisah Nabi, peranan dan kebudayaan Islam, maupun tokoh-tokoh keislaman yang memiliki kontribusi dalam peristiwa sejarah Islam, dan masih banyak kisah ataupun peristiwaperistiwa keIslaman. ${ }^{39}$ Dilihat dari pembahasannya, mata pelajaran Sejarah Kebudayaan Islam mempunyai peran penting dalam memotivasi siswa untuk mengetahui, memahami, dan menghayati peristiwa sejarah Islam. Didalam kisah-kisah dari peristiwa sejarah Islam memiliki nilai-

\section{Media, 2016).}

${ }^{37}$ H. H. P Daulay, Pemberdayaan Pendidikan Agama Islam Di Sekolah (Prenada

${ }^{38}$ M. Irsad, "Pengembangan Kurikulum Pendidikan Islam Di Madrasah (Studi Atas Pemikiran Muhaimin)," Jurnal Iqra': Kajian Ilmu Pendidikan 1, no. 2 (2016): 230-245.

${ }^{39}$ N. Nurjannah and N. O. Aci, "Implementasi Pendidikan Karakter Dalam Pembelajaran Sejarah Kebudayaan Islam Di Madrasah Ibtidaiyah,” Foramadiahi 11, no. 1 (2019): 1-20. 
nilai kearifan yang sangat berguna untuk dapat melatih kecerdasan serta membentuk watak, kepribadian dan sikap seseorang. ${ }^{40}$

Pembahasan materi Sejarah Kebudayaan Islam di tingkat Madrasah Ibtidaiyah, masih berkaitan dengan sejarah agama Islam yang dibawa nabi Muhammad, keteladanan Nabi Muhammad, serta perjalanan dakwa Nabi Muhammad. Ada beberapa di antara materi-materi tersebut yang kompetensi dasarnya yaitu bercerita tentang kelahiran Nabi Muhammad, keteladanan Nabi Muhammad dan dakwah Nabi Muhammad.

Sejarah Kebudayaan Islam, merupakan pelajaran yang memiliki peran penting untuk menambah dan memperluas wawasan pengetahuan tentang keislaman, karena tujuannya adalah pertama, untuk mengetahui dan memahami sejarah peradaban Islam. Kedua, mengenal tokoh-tokoh penting yang berkontribusi dalam memajukan dan memperluas peradaban Islam. $^{41}$ Dengan tujuan tersebut peserta didik dapat membangun daya intelektual dalam memahami kisah-kisah sejarah islam dan dapat menumbuhkan kecintaan kepada para tokoh-tokoh keislaman sehingga peserta didik dapat meneladaninya.

\section{G. METODE KISAH DALAM MENINGKATKAN MOTIVASI BELAJAR DAN KEMAMPUAN BERCERITA}

\section{Teknik Penerapan Metode Kisah dengan Gambar pada Pembelajaran SKI}

Sebuah kisah sebaiknya disajikan dan disampaikan dengan berbagai cara yang dapat menarik perhatian dan menumbuhkan rasa keingintahuan peserta didik, dengan begitu akan muncul pertanyaanpertanyaan dan tanggapan setelah guru bercerita. Akan lebih bermanfaat lagi jika cerita yang disampaikan memiliki kesesuaian dengan minat, kebutuhan dan kemampuan peserta didik.

Dari beberapa teknik cerita yang dapat digunakan, penelitian ini menggunakan teknik cerita dengan ilustrasi gambar, baik berupa gambar dari buku maupun gambar yang disediakan sendiri oleh guru.

${ }^{40}$ E. Sofi, "Pembelajaran Berbasis E-Learning Pada Mata Pelajaran Sejarah Kebudayaan Islam Kelas VIII Madrasah Tsanawiyah Negeri," Tanzhim 1, no. 1 (2017): 4964.

${ }^{41}$ Badri Yatim, Sejarah Peradaban Islam (Jakarta: Rajawali Pers, 2013), 24. 
Penggunaan gambar pada metode kisah dapat memperjelas pesan dari kisah yang diceritakan, selain itu juga dapat mengikat perhatian peserta didik pada alur cerita. ${ }^{42}$ Sehingga dapat memberikan gambaran kejadian pada kisah yang sedang diceritakan, dan memperkuat ketajaman daya ingat alur kisah tersebut.

Metode kisah dalam penerapannya pada pembelajaran Sejarah Kebudayaan Islam memiliki tahap-tahap tersendiri, di antaranya sebagai berikut:

a. Persiapan

Dalam langkah ini guru hendaknya mempersiapkan kisah yang akan diceritakan, bisa dengan merangkum atau mengambil inti-inti dari keseluruhan cerita. Selanjutnya guru memilih dan mempersiapkan gambar yang digunakan dalam bercerita, tentunya gambar yang dipilih harus sesuai dengan materi (kisah). Kemudian guru membagi siswa secara berkelompok, agar dapat mengatur tempat duduknya ketika dikelas.

b. Penyajian materi pembelajaran

Sebelum penyajian materi pembelajaran, guru hendaknya menyampaikan tujuan pembelajaran. Setelah itu, peserta didik diberi kesempatan membaca dan mempelajari materi terlebih dahulu, agar nantinya dapat lebih paham terhadap materi yang guru sampaikan . Berikut tahap-tahap penyajian materi pembelajaran, diantarnya yaitu:

1) Hendaknya dalam bercerita guru memakai bahasa dan kata yang mudah dimengerti dan dipahami oleh peserta didik .

2) Sebelum guru bercerita, sebaiknya peserta didik diperintah untuk mengamati gambar di buku maupun yang telah disediakan oleh guru. Dari pengamatan tersebut peserta didik memberikan tanggapan mengenai gambar yang ada.

3) Setelah memberikan tanggapan pada gambar, selanjutnya guru mulai bercerita.

4) Dalam menceritakan sebuah kisah hendaknya guru menyampaikannya berdasarkan periodesasi di mana setiap periode dalam sejarah merupakan bagian yang tak dapat

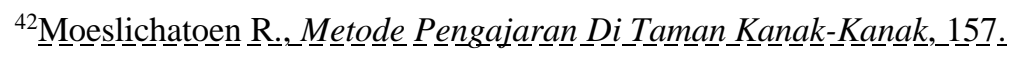


dipisahkan. Sambil bercerita, hendaknya menyelingkan pertanyaan-pertanyaan yang bertujuan untuk mengetahui inti dari cerita yang disampaikan.

5) Dalam bercerita guru dapat menuliskan setiap pembahasan baik itu periode, nama-nama tokoh yang berperan penting dalam sejarah Islam, sambil sesekali menunjuk gambar yang telah ditempel di papan tulis. Sehingga dengan cara ini peserta didik mudah mengingat kembali alur cerita dan dapat memberikan gambaran tentang kisah sejarah tersebut.

6) Ketika bercerita guru harus memperhatikan mimik wajah, gerakan tubuh, dan suara-suara yang dapat menambah menariknya kisah tersebut. Sehingga peserta didik dapat paham dan munculnya keinginan untuk mempelajari sejarah.

c. Korelasi

Pada setiap materi atau kisah yang disampaikan hendaknya menghubungkan pada peristiwa-peristiwa di kehidupan peserta didik. Dengan menghubungkan peristiwa atau kejadian yang dapat memberikan pengetahun tambahan serta kesadaran baru. Dengan cara ini akan muncul motivasi sekaligus dapat menambah wawasan pengetahuan untuk memahami nilai-nilai yang terdapat dalam kisah sejarah tersebut.

d. Kesimpulan

Guru memberikan kesimpulan dari kisah yang diceritakan, dengan mencatat point-point pembahasan di papan tulis sebagai rangkuman dari kisah yang disampaikan.

e. Evaluasi

Guru memberikan tugas kepada tiap kelompok untuk menceritakan ulang kisah sejarah yang telah disampaikan. Salah satu siswa akan ditunjuk untuk mewakili kelompoknya dalam bercerita. Setiap kelompok berdiskusi dan saling bekerjasama untuk memahami setiap alur dari kisah tersebut. Serta dapat menyampaikan intisari yang terkandung dalam kisah sejarah 
tersebut. Diantaranya nilai moral, dan keteladanan para tokohtokoh sejarah Islam. ${ }^{43}$

Dalam menerapkan metode kisah, hendaknya guru membuat desain dari tiap langkah-langkah metode kisah yang ada. Agar dalam pelaksanaannya dapat dilakukan dengan sistematis dan terstruktur. Perencanaan yang baik akan memberikan peluang keberhasilan dalam penerapannya. Oleh karena itu dalam menerapkan metode kisah ini butuh rancangan dan perencanaan yang tepat sehingga cerita yang disampaikan dapat menarik dan suasana belajar menjadi menyenangkan.

\section{Meningkatnya Motivasi Belajar dalam Pembelajaran SKI}

Ketika dalam diri seorang siswa tidak muncul sebuah keinginan atau hasrat yang dapat mendorongnya untuk melakukan kegiatan belajar. Maka yang harus dilakukan oleh pendidik (guru) adalah dengan mendatangkan motivasi dari luar diri siswa, agar muncul keinginan yang mendorong dirinya untuk melakukan aktivitas belajar demi tercapainya tujuan pembelajaran.

Salah satu upaya guru dalam mendatangkan motivasi dari luar diri siswa yaitu dengan menciptakan suasana pembelajaran yang menyenangkan. Dengan pembelajaran yang menyenangkan akan menumbuhkan ketertarikan atau keinginan dalam diri siswa, sehingga terdorong untuk bertindak dalam mencapai tujuan belajarnya. Selain itu akan muncul semangat yang tinggi dalam mengikuti proses pembelajaran karena bagi peserta didi kegiatan belajar adalah hal yang menyenangkan, bukan lagi hal yang membosankan.

Dalam mewujudkan pembelajaran yang menyenangkan seorang guru dituntut lebih kreatif untuk menciptakan inovasi belajar yang menarik, seperti halnya dengan metode kisah yang diterapkan dalam pembelajaran SKI. Penggunaan Metode kisah dirasa sangat relevan dengan materi pelajaran SKI yang pembahasannya berupa kisahkisah budaya Islam, tokoh-tokoh sejarah keislaman, dan peristiwaperistiwa Islam pada zaman dahulu.

${ }^{43}$ Chabib Thoha, Saifuddin Zuhri, and Syamsudin Yahya, Metodologi Pengajaran Agama (Semarang: Fakultas Tarbiyah IAIN Walisongo Semarang, 2004), 219-221. 
Dengan metode kisah yang sangat disukai oleh anak-anak, terutama pada tingkat usia Madrasah Ibtidaiyah, pembelajaran akan sangat dinikmati karena peserta didik merasa nyaman tanpa ada tekanan dalam belajar. Peserta didik yang merasakan asyiknya belajar berarti dalam dirinya terdapat unsur inner motivation yaitu adanya sebuah dorongan keingintahuan dengan diikuti daya atau usaha dalam mencari tahu sesuatu. ${ }^{44}$

Dapat disimpulkan dengan adanya indikator keingintahuan peserta didik dalam belajar, maka dapat diketahui telah timbulnya motivasi pada diri peserta didik yang datang dari luar dirinya yakni suasana pembeajaran yang menyenangkan.

\section{Kemampuan Bercerita dalam Pembelajaran SKI}

Pelajaran Sejarah Kebudayaan Islam mencakup pembahasan tentang kisah-kisah zaman dahulu, seperti asal-usul peristiwa Islam, kebudayaan Islam, dan tokoh-tokoh yang berperan penting pada sejarah Islam. Sering ditemukan, ketika peserta didik diberi tugas untuk menceritakan ulang tentang kisah sejarah, adanya rasa kebingungan dalam memulai bercerita. Hal ini terjadi karena pemahaman yang dimiliki peserta didik masih kurang. Kurangnya tingkat pemahaman, bisa disebabkan karena kurang tepatnya metode pembelajaran yang diterapkan.

Oleh sebab itu dengan menerapkan metode kisah, diharapkan terbentuknya suasana belajar dan mengajar yang lebih menarik, di mana peserta didik merasa senang dan nyaman mengikuti pembelajaran Sejarah Kebudayaan Islam. Perasaan menyenangkan akan berpengaruh pada daya serap siswa terhadap materi yang dijelaskan guru.

Seharusnya ada perbedaan antara daya serap materi yang menggunakan metode kisah dengan daya serap yang tidak menggunakan metode kisah. Diharapkan yang dengan menggunakan metode kisah dapat lebih paham mengenai materi (kisah) yang disampaikan.

${ }^{44}$ Khasan Bisri, "Strategi Guru Sejarah Kebudayaan Islam Dalam Merekonstruksi Materi Tentang Peperangan Dalam Peradaban Islam Di Ma Ali Maksum Krapyak Yogyakarta," Jurnal Pendidikan Agama Islam 13, no. 2 (April 24, 2017): 167. 
Selain itu adanya media gambar yang digunakan diharapkan dapat membantu daya ingat peserta didik pada materi kisah. Dengan dilengkapi media gambar, dapat memberikan gambaran nyata tentang kisah yang diceritakan. Sehingga kemampuan peserta didik dalam bercerita mengalami peningkatan.

\section{H. KESIMPULAN}

Berdasarkan pemaparan dan penjelasan di atas, penulis dapat menyimpulkan, dengan metode kisah yang digunakan untuk menyampaikan materi Sejarah Kebudayaan Islam dapat meningkatkan motivasi belajar dan kemampuan bercerita tentang sejarah Islam. Karena dengan metode tersebut, penyampaian materi Sejarah Kebudayaan Islam tidak lagi menoton dan membosankan. Metode kisah, dapat menjadikan kegiatan belajar mengajar lebih menyenangkan, membuat peserta didik merasa nyaman dan tertarik pada materi yang disampaikan. Peserta didik yang merasakan senangnya belajar, dalam dirinya akan muncul keinginan atau hasrat yang ditandai dengan adanya sebuah dorongan keingintahuan yang disertai daya atau usaha dalam mencapai tujuan belajar, inilah yang disebut motivasi belajar.

Selain itu dengan menerapkan metode kisah, dapat menjadi contoh bagi peserta didik dalam bercerita tentang sejarah Islam, khususnya ketika mendapatkan tugas menceritakan ulang kisah sejarah yang telah diceritakan oleh guru. Metode bercerita menggunakan gambar dapat menguatkan daya ingat peserta didik terhadap kisah sejarah tersebut. Sehingga dapat meningkatkan kemampun peserta didik dalam bercerita.

Adapun tahap-tahap dalam penerapan metode kisah yang harus diperhatikan oleh para pendidik yaitu diantaranya meliputi, perencaan, penyajian materi, korelasi, kesimpulan dan evaluasi. Mengenai perancangannya dapat disesuaikan dengan kebutuhan dan tujuan pembelajaran. 


\section{DAFTAR PUSTAKA}

Amirullah, and Heri Gunawan. Mencetak Anak Hebat. Jakarta: PT. Gramedia, 2014.

Angga, Dina Thalib, and Raja. "Motivasi Belajar, Kemandirian Belajar Dan Prestasi Belajar Mahasiswa Beasiswa Idikmisi Di UPBJJ UT Bandung." Jurnal Pendidikan Terbuka dan Jarak Jauh 15, no. 2 (September 2014).

Arifin, Bunyanul. "Mrtode Kisah Dalam Al-Qur'an Dan Sunnah Dan Urgensinya Dalam Pendidikan Karakter." Tadarus Tarbawy 1, no. 2 (2019): 109-123.

Arsyad, Junaidi. "Metode Kisah Dan Relevansinya Dengan Pendidikan Islam Kontemporer." Tazkiya: Jurnal Pendidikan Islam 6, no. 1 (2017): 1 16.

Bakar, Ramli. "The Effect Of Learning Motivation On Student's Productive Competencies In Vocational High School, West Sumatra." International Journal Of Asian Social Science 4, no. 6 (2014).

Baki, Nasir. Metode Pembelajaran Agama Islam. Makassar: Alauddin Universitas Press, 2012.

Bimo, Agus. Memahami Berbagai Aspek Bercerita. Jakarta: Raja Grafindo Persada, 2009.

Bisri, Khasan. "Strategi Guru Sejarah Kebudayaan Islam Dalam Merekonstruksi Materi Tentang Peperangan Dalam Peradaban Islam Di Ma Ali Maksum Krapyak Yogyakarta." Jurnal Pendidikan Agama Islam 13, no. 2 (April 24, 2017): 157-170.

Budiyanto, Mangun. Ilmu Pendidikan Islam. Yogyakarta: Griya Santri, 2010.

Daulay, H. H. P. Pemberdayaan Pendidikan Agama Islam Di Sekolah. Prenada Media, 2016.

Dhiena, N and dkk. Metode Pengembangan Bahasa. Jakarta: Universitas Terbuka, 2006.

Haq, Arifin. "Ketuntasan Belajar Siswa Pada Mata Pelajaran PAI Mealui Metode Kisah Di SD Islami Jiwa Nala Surabaya." Mukammil: Jurnal Kajian Keislaman 1, no. 2 (2018): 217-240.

Irfangi, M. "Implementasi Metode Kisah Dalam Pembelajaran Akidah Akhlak Di Madrasah Aliyah.” Jurnal Kependidikan 5, no. 1 (2017): 67-80. 
Irsad, M. "Pengembangan Kurikulum Pendidikan Islam Di Madrasah (Studi Atas Pemikiran Muhaimin)." Jurnal Iqra': Kajian Ilmu Pendidikan 1, no. 2 (2016): 230-245.

Kompri. Motivasi Pembelajaran Perspektif Guru dan Siswa. Bandung: PT Rosda Karya, 2016.

Kusnandi, Cecep, and Bambang Sujtipto. Media Pembelajaran Manual dan Digital. Bogor: Ghalia Indonesia, 2013.

Lee, J., and L. Martin. "Investigating Students' Perceptions of Motivating Factor of Online Class Discussions." Intrnational Review of Research in Open and Distance Learning 18, no. 5 (2017): 148-172.

Lubis, Siti Aminah. "Penerapan Metode Kisah Dengan Media Audiovisual Dalam Meningkatkan Hasil Belajar Sejarah Kebudayaan Islam Siswa Kelas X Madrasah Aliyah Negeri 1 Padangsidimpun.” Institut Agama Islam Negeri Padangsisimpuan, 2019.

Moeslichatoen R. Metode Pengajaran Di Taman Kanak-Kanak. Jakarta: PT. Rineka Cipta, 2004.

Muchtadir. "Meningkatkan Hasil Belajar Peserta Didik Pada Mata Pelajaran

SKI Melalui Penerapan Metode Kisah Dengan Model Pembelajaran Konstektual Di Kelas XI MA DDI Hasanuddin Kabupaten Maros." Skripsi, UIN Alauddin Makassar, 2019.

Mufaizin, Mufaizin, and Yassir Arafat. "Implementasi Metode Jibril dalam

Meningkatkan Kemampuan Membaca Al Qur'an Kelas C2 Tahsin Tilawah Lembaga Takhassusul Qur'an Darul Hikmah." AL-THIQAHJurnal Ilmu Keislaman 3.01 (2020): 39-54.

Mulasi, Syibran. "PROBLEMATIKA PEMBELAJARAN PAI PADA MADRASAH TSNAWIYAH DI WILAYAH BARAT SELATAN ACEH.” Jurnal Ilmiah Islam Futura 18, no. 2 (October 11, 2019): 269. Nizar, Samsul, and Zainal Efendi Hasibuan. Hadis Tarbawi. Jakarta: Kalam Mulia, 2011.

Nurjannah, N., and N. O. Aci. "Implementasi Pendidikan Karakter Dalam Pembelajaran Sejarah Kebudayaan Islam Di Madrasah Ibtidaiyah." Foramadiahi 11, no. 1 (2019): 1-20.

Presiden Republik Indonsia. "Undang-Undang Republik Indonesia Nomor 20 Tahun 2003 Tentang Sistem Pendidikan Nasional," 2003.

Putri, Hadisa. "Penggunaan Metode Kisah Untuk Mengembangkan Nilai Moral Anak TK/MI.” Jurnal Bioilmi 2, no. 2 (2016). 
Rosita, Mamik. "MEMBENTUK KARAKTER SISWA MELALUI METODE KISAH QURANI.” FITRAH:Jurnal Kajian Ilmu-ilmu Keislaman 2, no. 1 (June 1, 2016): 53.

Rudhumbu, Norman. "Motivational Strategies In The Teaching Of Primary School Mathematics In Zimbabwe." International Journal of Education Learning And Development UK 2, no. 2 (2014): 76-103.

Sadiman, Arief. Media pendidikan: Pengertian, Pengembangan dan Pemanfaatannya. Jakarta: Rajawali Pers, 2011.

Sani, Ridwan Abdullah. Inovasi Pembelajaran. Jakarta: Bumi Aksara, 2013. Sanjaya, Wina. Kurikulum dan pembelajaran, Teori dan praktek Pengembangan Kurikulum KTSP. Jakarta: Kencana, 2010.

Sari, Evi Yuliana. "Penerapan Metode Kisah Pada Pembelajaran Sejarah Kebudayaan Islam Kelas III MIN 8 Bandar Lampung." Skripsi, Universitas Islam Negeri Raden Intan, 2017.

Sofi, E. "Pembelajaran Berbasis E-Learning Pada Mata Pelajaran Sejarah Kebudayaan Islam Kelas VIII Madrasah Tsanawiyah Negeri.” Tanzhim 1, no. 1 (2017): 49-64.

Subur. Nilai Moral Berbasis Kisah. Yogyakarta: Kalimedia, 2015.

Sunhaji. Strategi Pembelajaran Konsep Dasar, Metode Dan Teknik Proses Belajar Mengajar. Yogyakarta: Pustaka Senja, 2015.

Tamara, Dayu. “ Penerapan Metode Bercerita Untuk Meningkatkan Keterampilan Berbicara Anak Kelompok A Di TK Pertiwi Keprabon Polanharjo Klaten Tahun Pelajaran 2013/2014.” Skripsi, Universitas Muhammadiyah, 2014.

Tampubolon, Manner. "Upaya Guru Meningkatkan Motivasi Belajar Siswa." Sabilarrasyad 1, no. 1 (2016): 100-118.

Thoha, Chabib, Saifuddin Zuhri, and Syamsudin Yahya. Metodologi Pengajaran Agama. Semarang: Fakultas Tarbiyah IAIN Walisongo Semarang, 2004.

Wahyuni, Ni Made, Wayan Koyan, and Gde Wawan Sudatha. "Penerapan Metode Bermain Peran Berbantuan Media Gambar Berseri Untuk Meningkatkan Kemampuan Bercerita Anak Kelompok B Di Tk Dharma Kusuma." Jurnal PAUD 1, no. 1 (2013): 1-11.

Ramdhan, T. W. (2018). Dimensi Moderasi Islam. Al-Insyiroh: Jurnal Studi Keislaman, 2(2), 29-48. 
Ramdhan, T. W. (2019). Model Pengembangan Kurikulum Multikultural. AlInsyiroh: Jurnal Studi Keislaman, 5(2), 39-53.

Yatim, Badri. Sejarah Peradaban Islam. Jakarta: Rajawali Pers, 2013.

Zellatifanny, Cut Medika, and Bambang Mudjiyanto. "TIPE PENELITIAN DESKRIPSI DALAM ILMU KOMUNIKASI." Diakom: Jurnal Media dan Komunikasi 1, no. 2 (December 28, 2018): 83-90. 